\title{
Analisis Kualitas Air Minum Pada Air Alkali Terionisasi
}

\author{
Nita Rosita \\ Pusat Laboratorium Terpadu, UIN Jakarta \\ Jl.Ir.H.Juanda No. 95 Ciputat Tangerang Selatan Banten 15412, Indonesia \\ nita4212@gmail.com
}

\begin{abstract}
Abstrak. Air sangat dibutuhkan oleh manusia, sehingga dapat dikatakan bahwa kualitas air merupakan salah satu syarat kualitas kesehatan manusia. Tingkat kesehatan masyarakat dapat diukur dari tingginya kualitas air minum. Beberapa tahun ini, masyarakat mengenal air alkali terionisasi sebagai air minum. Air alkali terionisasi adalah air yang memiliki derajat keasaman lebih dari 7. Berdasarkan hal itu, maka perlu dilakukan penelitian untuk mengetahui kualitas air alkali terionisasi sesuai dengan Peraturan Menteri Kesehatan No. 492 Tahun 2010. Sejauh ini belum ada penelitian tentang kualitas air alkali terionisasi berbagai merk di Kota tangerang Selatan. Sampel diambil dari 8 merk air alkali terionisasi yang ada di Kota Tangerang Selatan. Metode pengukuran sesuai dengan cara kerja Standar Nasional Indonesia (SNI) tentang kualitas air. Hasil pengukuran fisika dan biologi menunjukkan bahwa 8 merk yang diambil sebagai sampel memenuhi baku mutu sesuai peraturan yang ditetapkan. Hasil pengukuran kimia menunjukkan bahwa tiga sampel tidak memenuhi ketentuan yaitu pH, konsentrasi pH berkisar antara 7,61-8,90 dengan baku mutu 6,5-8,5. Sedangkan parameter kimia lain ammoniak, sulfat, nitrit, kesadahan, klorida,logam mangan dan logam besi sesuai syarat yang berlaku. Hasil penelitian menunjukkan bahwa hanya lima dari delapan merk air alkali terionisasi yang layak konsumsi sesuai dengan peraturan yang berlaku.
\end{abstract}

Kata Kunci. air alkali terionisasi, analisis kualitas air minum.

\begin{abstract}
Analysis Of The Quality Drinking Water In Ionized Alkaline Water]. Water is needed by humans live, so it can be said that water quality is one of the requirements for the quality of human health. The level of public health can be measured by the high quality of drinking water. In recent years, people have recognized ionized alkaline water as drinking water. Ionized alkaline water is water that has an acidity degree of more than 7. Based on this, it is necessary to conduct research to determine the quality of ionized alkaline water in accordance with Minister of Health Regulation No. 492 of 2010. So far there has been no research on the quality of ionized alkaline water from several brands in South Tangerang City. Samples were taken from 8 brands of ionized alkaline water in South Tangerang City. The measurement method is in accordance with the Indonesian National Standard (SNI) on water quality. The results of physical and biological measurements show that the 8 brands taken as samples comply with the quality standards with aplicable regulations. The chemical measurement results showed that the three samples did not fulfill the requirements, namely $\mathrm{pH}$, the $\mathrm{pH}$ concentration ranged from 7,61-8,90 with a quality standard of 6,5-8,5. Whereas other chemical parameters are ammonia, sulfate, nitrite, hardness, chloride, manganese metal and ferrous metal according to the applicable requirements. The results concluded that only five of the eight brands of ionized alkaline water were suitable for consumption by the applicable regulations.
\end{abstract}

Keywords: ionized alkaline water, Analysis Of The Quality Drinking Water.

\section{PENDAHULUAN}

Air sangat diperlukan oleh tubuh manusia seperti halnya udara dan makanan. Manusia tidak akan bisa bertahan hidup tanpa air. Selain berguna untuk manusia, air pun diperlukan oleh makhluk hidup lain misalnya hewan dan tumbuhan. Bagi manusia, air sebagian besar digunakan sebagai air minum baik yang dapat diminum langsung maupun yang harus dimasak terlebih dahulu sebelum diminum (Sulistyandari, Sulistyani, \& Raharjo, 2007).

Menurut Peraturan Menteri Kesehatan Republik Indonesia nomor 492 tahun 2010, air minum adalah air yang melalui proses pengolahan atau tanpa proses pengolahan yang memenuhi syarat kesehatan dan dapat langsung diminum. Saat ini masyarakat umum belum mengetahui tentang standar kualitas air minum. Air minum aman bagi kesehatan apabila memenuhi persyaratan fisika, mikrobiologis, kimiawi dan radioaktif (Amani \& Prawiroredjo, 2016).

Akhir-akhir ini ditengah masyarakat muncul air alkali terionisasi. Air alkali adalah air yang bersifat basa dan mempunyai dejat keasaman $(\mathrm{pH})$ umumnya berkisar antara $\mathrm{pH}$ 7-9,5. Air Alkali Terionisasi (AAT) adalah air yang mempunyai nilai potensial redoks yang tinggi yakni merupakan antioksidan yang baik karena nilai Oxydation Reduction Potensial (ORP) yang sangat negatif dan memiliki molekul air dalam kelompok yang lebih kecil daripada air biasa 
(micro-clustred). Manfaat air minum alkali terionisasi dalam kesehatan menurut Ignacio dkk, 2013 yaitu minuman yang berkhasiat untuk memperbaiki hyperadicity pada lambung, fermentasi usus yang abnormal, dyspepsia dan diare kronis (Emilia \& Mutiara, 2019).

Menurut penelitian yang telah dilakukan oleh (Emilia \& Mutiara, 2019) menunjukkan hasil tentang pengujian kualitas sampel air minum alkali terionisasi yang diproduksi mesin Kangen Water Tipe Leveluk SD 501 berdasarkan parameter fisika yaitu bau, rasa, warna, kekeruhan, jumlah zat padat terlarut, parameter kimia yaitu pengukuran $\mathrm{pH}$, klorida, kesadahan, flourida, kromium valensi 6, mangan, besi, nitrat, nitrit, seng, sulfat, sianida, alimunium, tembaga, dan pengujian biologi yaitu meliputi uji adanya E.Coli dan coliform sudah sesuai dengan persyaratan yang ditetapkan berdasarkan Peraturan Menteri Kesehatan (PERMENKES) Republik Indonesia Nomor 492 Tahun 2010.

Hasil penelitian terdahulu menunjukkan bahwa asupan air yang diionisasi oleh alkali memiliki berbagai efek baik bagi tubuh misal perbaikan diabetes, mengurangi sembelit, menahan akumulasi lemak di tubuh, pengangkatan spesies oksigen reaktif, pengurangan kerusakan kulit akibat sinar ultraviolet dan modulasi sistem imun. Beberapa contoh produk air minum alkali terionisasi di Kota Tangerang Selatan adalah Q plus, kangen water, pristine, milagros, dan lain-lain. Sejauh ini belum ada penelitian tentang kualitas air minum alkali terionisasi sesuai dengan peraturan PERMENKES Nomor 492 Tahun 2010. Berdasarkan hal tersebut, maka perlu dilakukan penelitian mengenai pengujian kualitas air minum pada air minum alkali terionisasi beberapa merk di Kota Tangerang Selatan. Tujuan penelitian untuk mengetahui kandungan atau kualitas air alkali terionisasi dan pengetahuan masyarakat tentang manfaat air alkali terionisasi untuk kesehatan.

\section{METODE}

Pengujian dilaksanakan di Pusat Laboratorium Terpadu UIN Syarif Hidayatullah Jakarta. Desain penelitian ini adalah kuantitatif. Pengambilan sampel menggunakan metode purposive sampling. Jumlah sampel sebanyak delapan (8) merk air alkali terionisasi diambil dari produksi air minum dalam kemasan (AMDK) yang ada di Kota Tangerang Selatan. Analisis pengujian berdasarkan Peraturan Menteri Kesehatan Nomor 492 Tahun 2010 tentang persyaratan Kualitas Air Minum baik parameter fisika, kimia maupun biologi.

Alat dan Bahan
Alat yang digunakan adalah Atomic Absorption Spektrophotometer (AAS), Spektrofotometer UV VIS, water quality checker (WQC), neraca analitik, $\mathrm{pH}$ meter, Glassware. Bahan yang digunakan dalam penelitian ini adalah aquadest, Larutan buffer (4, 7 dan 10), logam Fe 1000 mg/L, logam Mn 1000 mg/L, natrium nitroprussid, phenol, sodium hypochlorite, air alkali terionisasi. Bahan yang digunakan adalah pro analisis.

\section{Cara Kerja}

Parameter fisika meliputi suhu, TDS (total dissolve solid), kekeruhan diukur dengan alat WQC metode direct. Sedangkan bau dan rasa diuji secara organoleptik. Parameter kimia meliputi $\mathrm{pH}$, ammonia $\left(\mathrm{N}-\mathrm{NH}_{3}\right)$, nitrit $\left(\mathrm{N}-\mathrm{NO}_{2}\right)$, kesadahan, klorida, sulfat, logam mangan, logam besi dianalisis sesuai metode Standar Nasional Indonesia (SNI) tentang kualitas air. Sedangkan parameter biologi meliputi bakteri E.Coli (Escheria Coli) dan Total Coliform dianalisis sesuai dengan metode SNI. Hasil pengujian akan dibandingkan dengan baku mutu tentang persyaratan kualitas air minum sesuai dengan PERMENKES Nomor 492 Tahun 2010.

\section{HASIL DAN PEMBAHASAN}

Berdasarkan Tabel 1 Hasil pengujian terhadap 8 merk air alkali terionisasi, diperoleh data bahwa produksi air alkali terionisasi yang diproduksi industri ada tujuh sampel sedangkan produksi lokal ada satu sampel. Tujuh sampel air alkali yang diproduksi industri mempunyai nomor BPOM (Badan Pengawas Obat Makanan), kode SNI (Standar Nasional Indonesia) dan label halal MUI (Majelis Ulama Indonesia), sedangkan satu sampel produksi lokal belum memiliki nomor BPOM, kode SNI maupun label halal MUI, ini menunjukkan merk air alkali terionisasi produksi industri sudah mengikuti peraturan dalam SNI AMDK (Air Minum Dalam Kemasan).

"Air minum dalam kemasan (AMDK) adalah air baku yang telah diproses dan dikemas serta aman untuk diminum. Pada dasarnya air minum dalam kemasan diproses melalui 3 tahap, yaitu penyaringan, disinfeksi, dan pengisian. Penyaringan dimaksudkan untuk menghilangkan partikel padat dan gas-gas yang terkandung dalam air. Disinfeksi bertujuan untuk membunuh bakteri patogen dalam air. Pengisian merupakan tahap akhir proses produksi dimana air dimasukkan melalui sebuah peralatan yang dapat melindungi air tersebut dari kontaminasi selama pengisian kemasan "(Gafur, Kartini, \& Rahman, 2017). 
Jurnal Pendidikan dan Aplikasi Industri (UNISTEK)

Vol. 8 No.1 Februari 2021

p- ISSN : 0126 - 4036

e- ISSN : 2716 - 0416

Tabel 1. Pemeriksaan Label Keterangan Produk dan Sertifikasi

\begin{tabular}{ccccccc}
\hline \multirow{2}{*}{ NO } & KODE & \multicolumn{2}{c}{ PRODUKSI } & NO & KODE & LABEL \\
& SAMPEL AMDK & LOKAL & INDUSTRI & BPOM & SNI & HALAL MUI \\
\hline 1 & KW & $\sqrt{ }$ & & X & X & X \\
\hline 2 & MG & & $\sqrt{ }$ & $\sqrt{ }$ & $\sqrt{ }$ \\
\hline 3 & TL & & $\sqrt{ }$ & $\sqrt{ }$ & $\sqrt{ }$ \\
\hline 4 & QP & $\sqrt{ }$ & $\sqrt{ }$ & $\sqrt{ }$ \\
\hline 5 & AZ & $\sqrt{ }$ & $\sqrt{ }$ & $\sqrt{ }$ \\
\hline 6 & DM & $\sqrt{ }$ & $\sqrt{ }$ & $\sqrt{ }$ \\
\hline 7 & PR & $\sqrt{ }$ & $\sqrt{ }$ & $\sqrt{ }$ \\
\hline 8 & HY & $\sqrt{ }$ & $\sqrt{ }$ & $\sqrt{ }$ \\
\hline
\end{tabular}

*Sampel diambil dari Kota Tangerang Selatan

"Air minum dan air minum kemasan merupakan produk yang diatur secara ekstensif karena mempunyai peran yang sangat penting dalam kesehatan masyarakat. Peraturan tersebut dapat berasal dari peraturan internasional seperti WHO, negara, pemerintah daerah dan dalam beberapa kasus peraturan tersebut berasal dari asosiasi misalnya IBWA. Umumnya peraturan tersebut merupakan standar yang didasarkan pada pertimbangan kesehatan" (Agustini, 2017).

"Sebagai produk industri, AMDK ditetapkan sebagai produk yang penerapan SNI nya diberlakukan secara wajib. Penerapan diperlukan untuk meningkatkan kemampuan bersaing, menciptakan persaingan bisnis yang adil, untuk menjamin kesehatan, keselamatan, dan keamanan konsumen serta untuk melindungi lingkungan. Pemberlakuan SNI AMDK sejalan dengan pemberlakuan standar kualitas air minum sesuai dengan PERMENKES Nomor 492 Tahun 2010" (Agustini, 2017).

Tabel 2 menunjukkan air alkali terionisasi tidak berbau dan berasa. Hasil suhu seluruh sampel masih dibawah baku mutu yang diperbolehkan yaitu suhu ruang $\pm 3{ }^{\circ} \mathrm{C}$, rentang suhu air antara $23,56-23,98{ }^{\circ} \mathrm{C}$. "Suhu dapat mempengaruhi sejumlah parameter lain mutu air. Laju reaksi kimia dan biokimia meningkat dengan meningkatnya suhu. Kelarutan gas menurun dan kelarutan mineral meningkat seiring meningkatnya suhu. Laju pertumbuhan organisme akuatik meningkat dan laju respirasi mereka menurun dengan meningkatnya suhu, kebanyakan organisme mempunyai kisaran suhu yang berbeda dalam reproduksi dan kompetisi" (Gafur, Kartini, \& Rahman, 2017).

Berdasarkan Tabel 2 di atas menunjukkan bahwa semua air alkali $100 \%$ memenuhi standar kualitas air minum dari segi fisika. Sesuai dengan hasil pengujian rentang konsentrasi TDS berkisar antara 19-123 mg/L dengan konsentrasi TDS maksimum yang diizinkan adalah $1000 \mathrm{mg} / \mathrm{L}$. "TDS dalam air minum tidak diinginkan karena dapat menimbulkan warna, rasa, dan bau yang tidak sedap. Beberapa senyawa kimia pembentuk TDS bersifat racun dan merupakan senyawa organik bersifat karsinogenik" (Emilia \& Mutiara, 2019).

Tabel 2: Data Hasil Uji Parameter Fisika

\begin{tabular}{ccccc}
\hline \multirow{2}{*}{ NO } & $\begin{array}{c}\text { KODE } \\
\text { SAMPEL AMDK }\end{array}$ & Suhu ${ }^{\circ} \mathbf{C}$ & $\begin{array}{c}\text { PARAMETER } \\
\text { TDS (mg/L) }\end{array}$ & Kekeruhan (NTU) \\
\hline 1 & KW & 23,56 & 123 & 0 \\
\hline 2 & MG & 23,84 & 110 & 0 \\
\hline 3 & TL & 23,90 & 114 & 0 \\
\hline 4 & QP & 23,60 & 12 & 0 \\
\hline 5 & AZ & 23,98 & 30 & 0 \\
\hline 6 & DM & 23,90 & 15 & 0 \\
\hline 7 & PR & 23,91 & 111 & 0 \\
\hline 8 & HY & 23,91 & 19 & \\
\hline
\end{tabular}

${ }^{1)}$ Semua sampel AMDK tidak berbau dan tidak berasa

Tabel 2 terlihat nilai kekeruhan masing-masing sampel 0 (nol) NTU dengan konsentrasi kadar kekeruhan maksimum yang diperbolehkan adalah 5 (lima) NTU. Kekeruhan terjadi karena adanya koloid kecil dan pertumbuhan mikroorganisme dalam air, semakin banyak koloid dan mikroorganisme maka semakin tinggi konsentrasi kekeruhannya. Menurut (Emilia \& Mutiara, 2019) "kekeruhan menggambarkan sifat optik air yang ditentukan berdasarkan banyaknya cahaya yang diserap dan dipancarkan oleh bahan-bahan yang terdapat di dalam air. Kekeruhan (NTU) menggambarkan sifat optik air. Data diatas menunjukkan bahwa kualitas air alkali sudah baik dari segi parameter fisika". 


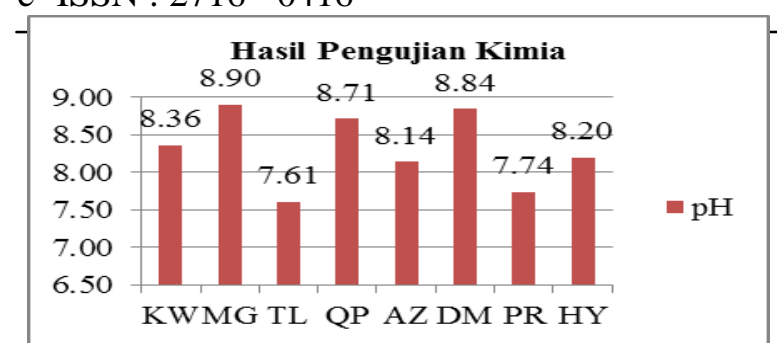

Gambar 1. Data Hasil Uji Kimia pH

Berdasarkan Gambar 1 Hasil analisis menunjukkan bahwa tingkat $\mathrm{pH}$ berkisar antara 7,618,90 . Beberapa sampel air alkali menunjukkan di atas baku mutu yang diizinkan yaitu 6,5-8,5. Air alkali terionisasi yang tidak sesuai yaitu $\mathrm{MG}(8,90)$, QP $(8,71)$, dan DM $(8,84)$. “derajat keasaman atau $\mathrm{pH}$ merupakan nilai yang menunjukkan aktivitas ion hidrogen dalam air. Nilai $\mathrm{pH}$ dipengaruhi oleh beberapa parameter, antara lain aktivitas biologi, suhu, kandungan oksigen dan ion-ion” (Rosita, 2014).

"Nilai pH yang lebih dari 7 menunjukkan sifat korosi yang rendah sebab semakin rendah $\mathrm{pH}$, maka sifat korosinya semakin tinggi. nilai $\mathrm{pH}$ yang lebih besar dari 7 memiliki kecenderungan untuk membentuk kerak dan kurang efektif dalam membunuh bakteri sebab akan lebih efektif pada kondisi netral atau bersifat asam lemah." (Amani \& Prawiroredjo, 2016).

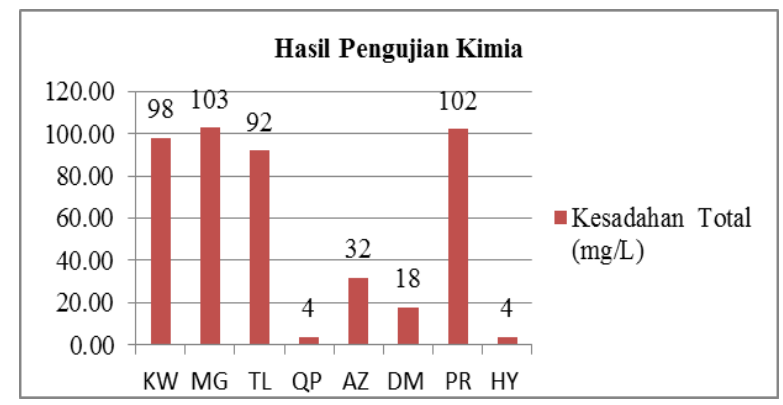

Gambar 2. Data Hasil Uji Kimia Kesadahan

Berdasarkan Gambar 2 menunjukkan bahwa rentang konsentrasi kesadahan adalah 4-103 mg/L, maksimum konsentrasi kesadahan yang diperbolehkan yaitu $500 \mathrm{mg} / \mathrm{L}$. Nilai terkecil dengan kode QP (4 $\mathrm{mg} / \mathrm{L}$ ) dan nilai terbesar dengan kode MG (103 mg/L). "Kesadahan merupakan sifat air yang disebabkan oleh adanya ion-ion (kation logam valensi dua yang mampu bereaksi dengan sabun membentuk kerak air. Definisi dari kesadahan total adalah kesadahan yang disebabkan oleh adanya ion $\mathrm{Ca}^{2+}$ dan $\mathrm{Mg}^{2+}$ secara bersama-sama” (Musiam, Darmiani, \& Putra, 2015).

"Penetapan kesadahan total ini menggunakan metode kompleksiometri, yaitu pembentukan kompleks berwarna oleh logam. Dengan menggunakan larutan baku $\mathrm{Na}_{2}$ EDTA dan indikator EBT. Bila penambahan indikator EBT pada larutan yang mengandung ion $\mathrm{Ca}$ dan $\mathrm{Mg}$ pada $\mathrm{pH} 10 \pm 0,1$ larutan akan akan menjadi merah anggur. Bila kemudian dititrasi dengan $\mathrm{Na}_{2}$ EDTA, ion $\mathrm{Ca}$ dan $\mathrm{Mg}$ sudah terikat, larutan yang berwarna merah anggur berubah menjadi biru sebagai titik akhir titrasi" (Wulandari, 2017).

Berdasarkan Tabel 3 hasil pengujian parameter nitrit, ammonia, klorida, sulfat, logam Mn (Mangan), dan Logam Fe (Besi) sesuai standar baku mutu PERMENKES Nomor 492 Tahun 2010. Rentang konsentrasi logam Mangan antara 0,014-0,033 mg/L dengan baku mutu yang diperbolehkan adalah 0,4 $\mathrm{mg} / \mathrm{L}$. Konsentrasi nitrit antara 0,001-0,023 mg/L dengan maksimum konsentrasi yang diizinkan adalah $3 \mathrm{mg} / \mathrm{L}$. "Nitrit bersifat racun karena dapat bereaksi dengan hemoglobin darah, sehingga darah tidak dapat mengangkut oksigen, disamping itu juga nitrit membentuk nitrosamin (RRN-NO) pada air buangan tertentu dan dapat menimbulkan kanker. Nitrat $\left(\mathrm{NO}^{3-}\right)$ dan nitrit $\left(\mathrm{NO}^{2-}\right)$ adalah ion-ion anorganik alami, yang merupakan bagian dari siklus nitrogen" (Rosita, 2014).

Tabel 3 menunjukkan rentang konsentrasi ammoniak antara 0,10-0,16 mg/L dengan baku mutu yang ditetapkan yaitu $1,5 \mathrm{mg} / \mathrm{L}$. Kandungan ammonia bisa berasal dari limbah domestik dan bisa juga berasal dari sumber air tanah. "

Tabel 3 menunjukkan rentang konsentrasi sulfat berkisar antara 2-43 $\mathrm{mg} / \mathrm{L}$ dengan kadar maksimum yang diperbolehkan yaitu $250 \mathrm{mg} / \mathrm{L}$. Nilai terkecil dengan kode QP (2 mg/L) dan nilai terbesar dengan kode HY (43 mg/L). Kandungan sulfat yang tinggi akan mengakibatkan iritasi pada saluran pencernaan dan memiliki efek rasa dengan penggunaan yang berlebihan.

Tabel 3. Data Hasil Uji Kimia

\begin{tabular}{cccccccc}
\hline NO & \multirow{2}{*}{ KODE } & \multicolumn{6}{c}{ PARAMETER } \\
& SAMPEL AMDK & Nitrit & Ammonia & Klorida & Sulfat & Logam Besi & Logam Mangan \\
& & $(\mathbf{m g} / \mathbf{L})$ & $(\mathbf{m g} / \mathbf{L})$ & $(\mathbf{m g} / \mathbf{L})$ & $(\mathbf{m g} / \mathbf{L})$ & $(\mathbf{F e ~ m g / L )}$ & $(\mathbf{M n}$ mg/L) \\
\hline 1 & KW & 0,023 & 0,14 & 17,14 & 8,00 & $<0,023$ & $<0,014$ \\
\hline 2 & MG & $-0,002$ & 0,14 & 4,57 & 4,00 & $<0,023$ & $<0,014$ \\
\hline 3 & TL & 0,005 & 0,12 & 4,57 & 5,00 & $<0,023$ & $<0,014$ \\
\hline 4 & QP & $-0,001$ & 0,16 & 4,57 & 2,00 & $<0,023$ & $<0,014$ \\
\hline 5 & AZ & $-0,001$ & 0,15 & 4,57 & 9,00 & $<0,023$ & $<0,014$ \\
\hline 6 & DM & $-0,001$ & 0,12 & 4,57 & 7,00 & $<0,023$ & 0,033 \\
\hline 7 & PR & 0,005 & 0,10 & 4,57 & 2,00 & $<0,023$ & $<0,014$ \\
\hline
\end{tabular}




\begin{tabular}{llll}
8 & & & \\
\hline HY & 0,007 & 0,11 & 4,57
\end{tabular}

Nilai klorida pada Tabel 3 berkisar antara 4,57$17,14 \mathrm{mg} / \mathrm{L}$. Batas maksimum klorida dalam air minum adalah $250 \mathrm{mg} / \mathrm{L}$. Menurut (Wulandari, 2017) "analisa kadar klorida air dilakukan menggunakan titrasi argentometri metode Mohr. Metode Mohr dapat digunakan untuk menentapkan kadar klorida dalam suasana netral dengan larutan standar $\mathrm{AgNO}_{3}$ dan penambahan $\mathrm{K}_{2} \mathrm{CrO}_{4}$ sebagai indikator. Titrasi ini dilakukan dalam suasana netral atau dengan sedikit alkalis, pH 6,5-9,0. Apabila ion klorida telah habis diendapkan oleh ion perak, maka ion kromat akan bereaksi membentuk endapan perak kromat yang berwarna coklat/merah bata sebagai titik akhir titrasi”. "Kadar klorida yang tinggi dapat berbahaya bagi kesehatan diantaranya dapat bersifat merusak atau korosif pada kulit dan peralatan, selain itu juga berpotensi merusak sistem pernafasan manusia dan hewan" (Wulandari, 2017).

Berdasarkan Tabel 3 menunjukkan hasil bahwa konsentrasi logam besi (Fe) total adalah <0,023 mg/L. Sampel air alkali menunjukkan bahwa semua air alkali $(100 \%)$ memenuhi standar maksimum yang ditetapkan adalah $0,3 \mathrm{mg} / \mathrm{L}$. Hasil kandungan Fe total dalam pemeriksaan bisa disebabkan oleh terkikisnya alat-alat yang digunakan dalam produksi dan kondisi air baku yang digunakan apabila sumber baku adalah air tanah.

Tabel 4. Data Hasil Uji Biologi

\begin{tabular}{|c|c|c|c|}
\hline \multirow[b]{2}{*}{ NO } & \multirow[b]{2}{*}{$\begin{array}{l}\text { KODE SAMPEL } \\
\text { AMDK }\end{array}$} & \multicolumn{2}{|c|}{ BAKTERI } \\
\hline & & $\begin{array}{c}\text { Total Coliform } \\
(J U M L A H \text { per } 100 \mathrm{~mL})\end{array}$ & $\begin{array}{c}\text { Escheria Coli } \\
\text { (JUMLAH per } 100 \mathrm{~mL})\end{array}$ \\
\hline 1 & KW & 0 & 0 \\
\hline 2 & $\mathrm{MG}$ & 0 & 0 \\
\hline 3 & TL & 0 & 0 \\
\hline 4 & QP & 0 & 0 \\
\hline 5 & $\mathrm{AZ}$ & 0 & 0 \\
\hline 6 & $\mathrm{DM}$ & 0 & 0 \\
\hline 7 & $\mathrm{PR}$ & 0 & 0 \\
\hline 8 & $\mathrm{HY}$ & 0 & 0 \\
\hline
\end{tabular}

Tabel 4 di atas menunjukkan bahwa hasil pengujian bakteri Coliform dan E Coli pada 8 sampel air alkali terionisasi mempunyai nilai 0 jumlah per 100 mL. Ini menunjukkan sampel air minum alkali terionisasi sesuai dengan baku mutu yang diizinkan yaitu 0 per $100 \mathrm{~mL}$ sampel. "Apabila air minum yang dikonsumsi melebihi nilai standard baku mutu yang ditetapkan akan mengakibatkan penyakit. Salah satu penyakit yang disebabkan oleh air minum yang kualitas bakteri E. Coli buruk adalah diare" (Gafur, Kartini, \& Rahman, 2017).

"Terjadinya kontaminasi bakteri E. Coli pada air minum bisa diakibatkan karena sumber-sumber air dialam pada umumnya mengandung bakteri, baik air angkasa, air permukaan, maupun air tanah. Jumlah dan jenis bakteri berbeda-beda sesuai dengan tempat dan kondisi yang mempengaruhinya. Saat ini mutu lingkungan air menurun yang berdampak pada kualitas ketersediaan air sebagai bahan baku air minum" (Gafur, Kartini, \& Rahman, 2017).

Berdasarkan data hasil penelitian menunjukkan bahwa 3 dari 8 merk air alkali terionisasi tidak layak konsumsi dari segi kimia yaitu $\mathrm{pH}$, hanya 5 merk air alkali terionisasi yang memenuhi syarat sesuai dengan PERMENKES Nomor 492 Tahun 2010 tentang kualitas air minum baik dari segi fisika, kimia maupun biologi. Pengujian kualitas produk yang telah dilakukan tidak bisa menjamin air yang dihasilkan layak, bebas dari pencemaran dan aman bagi kesehatan masyarakat. Pengawasan terhadap produksi air alkali terionisasi perlu ditingkatkan mengingat banyaknya masyarakat yang mengkonsumsi air tersebut.

Menurut penelitian yang dilakukan oleh (Sukohar \& Catur, 2016) "AAT dapat menjaga tubuh kita dari berbagai masalah penyakit mematikan yang disebabkan karena radikal bebas. Penggunaan AAT dapat membantu kita untuk mempertahankan gaya hidup sehat dan dapat mencegah berbagai penyakit seperti kanker". Begitu juga dengan penelitian yang dilakukan oleh (Wahyuningtiyas, Arkhaesi, \& Hardaningsih, 2016) "terdapat perbedaan yang bermakna kualitas hidup anak asma usia 6-14 tahun setelah diberikan air alkali terionisasi”.

\section{KESIMPULAN}

Pengujian kualitas air alkali terionisasi menunjukkan hasil bahwa $100 \%$ sampel memenuhi syarat fisika dan biologi. Nilai parameter fisika suhu (23,56-23,98 $\left.{ }^{\circ} \mathrm{C}\right)$, TDS (19-123 mg/L) dan kekeruhan (0 NTU). Nilai parameter biologi bakteri E Coli dan Coliform 0 jumlah per $100 \mathrm{~mL}$. Sedangkan parameter kimia menunjukkan ada satu parameter yang tidak sesuai syarat yaitu derajat keasaman $(\mathrm{pH})$, rentang konsentrasi $\mathrm{pH} 7,61-8,90$. Sedangkan nilai parameter kimia lain sulfat (2-43 mg/L), klorida (4,57-17,14 $\mathrm{mg} / \mathrm{L})$, ammonia (0,10-0,16 mg/L), kesadahan (4-103 $\mathrm{mg} / \mathrm{L})$, nitrit $(0,001-0,023 \mathrm{mg} / \mathrm{L})$, logam besi $(<0,023$ $\mathrm{mg} / \mathrm{L})$, dan logam mangan $(0,014-0,033 \mathrm{mg} / \mathrm{L})$ sesuai dengan baku mutu yang ditetapkan. Hasil penelitian 


\section{Jurnal Pendidikan dan Aplikasi Industri (UNISTEK)}

\section{Vol. 8 No.1 Februari 2021}

p- ISSN : 0126 - 4036

e- ISSN : 2716 - 0416

menunjukkan hanya 5 merk air alkati terionisasi dari 8 merk air alkali terionisasi yang layak konsumsi sesuai dengan Peraturan Menteri Kesehatan No. 492 Tahun 2010 tentang kualitas air minum secara fisika, kimia dan biologi. Produsen seharusnya melengkapi dan mengecek kembali pelabelan yang belum memenuhi syarat yang ditetapkan dan menjaga kualitas produk. Perlu dilakukan penelitian lebih lanjut mengenai air alkali terionisasi baik dari kemasan botol maupun galon.

\section{DAFTAR PUSTAKA}

Agustini, S. (2017). Harmonisasi Standar Nasional (SNI) Air Minum dalam Kemasan dan Standar Internasional. Majalah Teknologi Agro Industri., 9(2), 30-39.

Amani, F., \& Prawiroredjo, K. (2016). Alat Ukur Kualitas Air Minum dengan Parameter $\mathrm{pH}$, Suhu, Tingkat Kekeruhan, dan Jumlah Padatan Terlarut. JETri., 14(1), 49-62.

Emilia, I., \& Mutiara, D. (2019). Parameter Fisika, Kimia dan Bakteriologi Air Minum Alkali Terionisasi Yang Diproduksi Mesin Kangen Water Leveluk Sd 501. Sainmatika: Jurnal Ilmiah Matematika dan Ilmu Pengetahuan Alam univpgri., 16(1), 67-73.

Gafur, A., Kartini, A.D., \& Rahman. (2017). Studi Kualitas Fisik Kimia dan Biologis pada Air Minum dalam Kemasan Berbagai Merek yang Beredar di Kota Makassar Tahun 2106. Higiene., 3(1), 37-46.

Musiam, S., Darmiani, S., \& Putra, A.M. (2015). Analisis Kuantitatif Kesadahan Total Air Minum Isi Ulang yang Dijual Di Wilayah Kayu Tangi Kota Banjarmasin. Jurnal Ilmiah Manuntung., 1(2), 145-148

Pemerintah Indonesia . (2010). Peraturan Menteri Kesehatan No. 492 Tahun 2010 Tentang Persyaratan Kualitas Air Minum.

Rosita, Nita. 2014. Analisis Kualitas Air Minum Isi Ulang Beberapa Depot Air Minum Isi Ulang (DAMIU) di Tangerang Selatan. Jurnal Kimia Valensi., 4(2), 134-141.

Sukohar, A., \& Catur, M.M. (2016). Air Alkali Terionisasi Pencegahan Termutakhir Timbulnya Kanker. Majority., 5(2), 74-80.

Sulistyandari, H., Sulistyani, \& Raharjo, M. (2007). Faktor-Faktor Yang Berhubungan Dengan Kontaminasi Detergen Pada Air Minum Isi Ulang di Depot Air Minum Isi Ulang (DAMIU) di Kabupaten Kendal Tahun 2009. Jurnal Kesehatan Lingkungan Indonesia., 6(2), 54-58.

Wahyuningtyas, Y., Arkhaesi, N., \& Hardaningsih, G. (2016). Pengaruh Pemberian Air Alkali Terionisasi Terhadap Kualitas Hidup Anak 
Jurnal Pendidikan dan Aplikasi Industri (UNISTEK)

Vol. 8 No.1 Februari 2021

p- ISSN : 0126 - 4036

e- ISSN : 2716 - 0416

Jurnal Pendidikan dan Aplikasi Industri, Volume 8, Nomor 12021 |68 